\title{
TANITMA 2: Arab women in the field: studying your own society (contemporary issues in the Middle East) (edited by Soraya Altorki and Camillia El-Solh' Syrcause University Press, ${ }^{\text {st }}$ edition paperback 1988, p. 196)
}

\section{Zehra GÜVEN KILIÇARSLAN ${ }^{1}$}

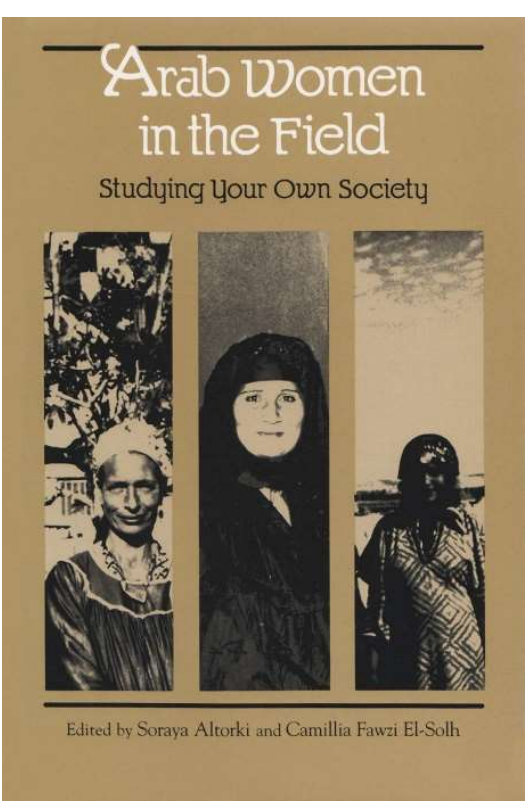

Arab Women in the Field is the collection of six articles written by Arab women social scientists. These six women have a number of common traits. They are originally all from the Arab land, Middle East, all educated in the West, they are all social scientists and they are all 'women.' All of them are the members of the societies they studied (e.g. Palestinian, Saudi Arabian, Lebanese, Egyptian, and Jordanian). They use their theoretical knowledge which is the result of their educational experiences in Western countries and rethink the theory of the West in the light of their experiences in the East. For their research, the most important informants were women. In fact, four of them conducted their research on women issues. Also, all of their researches were conducted in the 1970s and 1980s. In this era, as Altorki and el-Solh indicates in the Introduction, there was an increasing interest in studying of gender issues in the West and this influenced these six Arab women as well. All of these shared characteristics are to show the advantages and disadvantages of being indigenous (as well as foreign) and women in the Middle East and to bring out a study which is far from bias and common conception.

It is not common that academic literature is able to illustrate theory and its practice in such a personally engaging way as Arab Women in the Field does. Through a series of chapters highlighting the dissonances between cultures concerning gender roles, familial relations, and socioeconomic status, the book's contributors chronicle their own experiences in the field and how their own upbringing shaped the "structured reality" of their research methods. Coming from the idea of "the sociology of knowledge" - which is mentioned in Orientalism by Edward Said - this book poses certain challenges to the construction of knowledge in Western academics on Arab characterization by taking its reader to a journey wearing the researcher'/ the producers' shoes. Identifying that "the production of knowledge and the validity of its content are intimately connected with the social position of its producer" puts the fieldwork and its actor, the researcher, who constructs the fieldwork in the heart of the science. The specific focus, therefore, is the certain two assumptions of objectivity/subjectivity of social scientist in terms of her insider/outsider or foreign/indigenous position. This argument targets the researchers' identity. This means the gender of the researcher and the ethnic origins at first hand. There is a history behind the subjectivity being ascribed to feminine and objectivity to masculine identity in the common discourse of traditional Orientalist social sciences. Thus, the compilation of these articles tackles this 'structured' bias from different angles by demonstrating female approach and methodologies which were employed very functionally and self-consciously in the choice of topic, communication, collection of data and interpretation, analysis of the research subject.

Öğr. Gör. Dr., Eskișehir Osmangazi Üniversitesi, Fen Edebiyat Fakültesi, Karşılaştırmalı Edebiyat Bölümü, Doğu Dilleri ve Edebiyatları ABD (Eskişehir, Türkiye), zguvenki@outlook.com, ORCID ID: 0ooo-0003-2784-0715 [Makale kayıt tarihi: 20.11.2019-kabul tarihi: 20.03.220; DOI: 10.29000/rumelide.706555] 
BOOK REVIEW 2: Arab women in the field: studying your own society (contemporary issues in the Middle East) (edited by Soraya Altorki and Camillia El-Solh' Syrcause University Press, $1^{\text {st }}$ edition paperback 1988, p. 196)/ Z. Güven Kıliçarslan (pp. 741-742)

The book begins with a comprehensive introduction, one that is necessary for grounding the reader in the intricacies of dealing with the aforementioned "structured reality." By pointing out this existence of the relationship between female Arab researchers and their subjects as well as all of the social circumstances that could affect those relationships, the aim of this book is set out to be twofold: First one is to be an expository account of the situations faced by these researchers and the individual changes occurring therewith and the second one is to list in detail a number of cultural internalities and externalities that either helped or hindered the collection of data.

The first aim is easily achieved, as all of the contributors detail how and when they became involved in anthropology as well as how interactions with their personal histories were to potentially shape their research. The second aim is also achieved, insofar as the importance of gender as is conceived in today's society is relatively downplayed in favor of highlighting familial and social roles where gender is merely a factor among many in how these researchers' personal interactions were shaped. This is a refreshing departure from previous feminist academic studies on gender issues and similarly from the contemporary political depictions of women as being part of a singular social narrative that is predicated on submission to males in Islamic societies.

Even after three decades, this book still stands as a highly important contribution to literature that enlightens the reader of the workings of such intricacies of field works, the debates and journey of change in the social sciences. Suad Joseph, Lila Abu-Lughod, Soraya Altorki, Camilla Fawzi El-Solh, Soheir Mosrsy and Seteney Shami, all share very honest and explicit accounts of realizations, dilemmas and insights of observation and rendering of people's belief and behaviors has impact on depth readers' thinking. The findings of diverse subject matters and communities make such good case of the blurring lines between emic and etic accounts of belief and behavior as well as of public and private spheres of gender, power and expression. Many stereotypes and conceptual problems on identity, class, gender and ethnicity are pointed and resolved through these valuable examples of women scientists' research. 